\title{
Record of Decision Remedial Alternative Selection for the Grace Road Site (631-22G) Operable Unit: Final Action
}

by

E. Palmer

Westinghouse Savannah River Company

Savannah River Site

Aiken, South Carolina 29808

\section{RECEIVED \\ JAN 151998 \\ 0871}

This paper was prepared in connection with work done under the above contract number with the U.S. Department of Energy. By acceptance of this paper, the publisher and/or recipient acknowledges the U.S. Government's right to retain a nonexclusive, royalty-free license in and to any copyright covering this paper, along with the right to reproduce and to authorize others to reproduce all or part of the copyrighted paper. 


\section{DISCLAIMER}

This report was prepared as an account of work sponsored by an agency of the United States Government. Neither the United States Government nor any agency thereof, nor any of their employees, makes any warranty, express or implied, or assumes any legal liability or responsibility for the accuracy, completeness, or usefulness of any information, apparatus, product, or process disclosed, or represents that its use would not infringe privately owned rights. Reference herein to any specific commercial product, process, or service by trade name, trademark, manufacturer, or otherwise does not necessarily constitute or imply its endorsement, recommendation, or favoring by the United States Government or any agency thereof. The views and opinions of authors expressed herein do not necessarily state or reflect those of the United States Government or any agency thereof.

This report has been reproduced directly from the best available copy.

Available to DOE and DOE contractors from the Office of Scientific and Technical Information, P. O. Box 62, Oak Ridge, TN 37831; prices available from (423) 576-8401.

Available to the public from the National Technical Information Service, U. S. Department of Commerce, 5285 Port Royal Road, Springfield, VA 22161. 


\section{DISCLAIMER}

Portions of this document may be illegible electronic image products. Images are produced from the best available original document. 
United States Department of Energy

Savannah River Site

\section{Record of Decision}

Remedial Alternative Selection

for the

Grace Road Site (631-22G)

Operable Unit: Final Action(U)

WSRC-RP-96-O0160

Revisional

January 1997

Westinghouse Savannah River Company

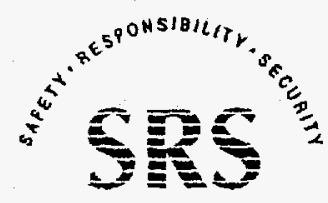

Savannah River Site

Aiken, South Carolina 29808

Prepared for the U.S. Department of Energy Under Contract DE-AC09-96SR18500 
This page intentionally left blank 
Record of Decision Remedial Alternative Selection (U)

Grace Road Site (631 -22G) Operable Unit: Final Action

WSRC-RP-96-O0160

Revisional

January 1997

Savannah River Site

Aiken County, South Carolina

Prepared by:

Westinghouse Savannah River Company for the

U.S. Department of Energy Under Contract DE-AC09-96SR1 8500

Savamnah River Operations Office

Aiken, South Carolina 
This page left intentionally blank 


\section{DECLARATION FOR THE RECORD OF DECISION}

\section{Unit Name and Location}

Grace Road Site (SRS Bldg.\#631-22G)

Savannah River Site

Aiken, South Carolina

The Grace Road Site (631 -22G) is listed as a Resource Conservation and Recovery Act (RCRA) 3004(U)" solid waste management uniUComprehensive Environmental Response, Compensation and Liability Act (CERCLA) unit in Appendix C of the Federal Facility Agreement (FFA) for the Savamah River Site.

\section{Statement of Basis and Purpose}

This decision document presents the selected remedial action for the Grace Road Site located at the Savannah River Site near Aiken, South Carolina. The selected action was developed in accordance with CERCLA, as amended, and to the extent practicable, the National Oil and Hazardous Substances Pollution Contingency Plan (NCP). The selected remedy satisfies both CERCLA and RCRA 3004(u) requirements. This decision is based on the Administrative Record File for this specific RCRAJCERCLA unit.

\section{Description of the Selected Remedy}

The results of the Resource, Conservation and Recovery Act Facility Investigation/Comprehensive Environmental Response Compensation and Liability Act Remedial Investigation, indicate that the Grace Road Site poses no unacceptable risk to human health or the environment. Therefore, no action is needed at the Grace Road Site. This is the final RCRA/CERCLA action for the Grace Road Site. The South Carolina Department of Health and Environmental Control has modified the SRS RCRA permit to incorporate the selected remedy.

\section{Declaration Statement}

Based on the results of the remedial investigation, no action is necessary at the Grace Road Site to ensure the protection of human health and the environment. Since Grace Road Site poses no unacceptable threat to human health or the environment, and no action is needed, the CERCLA Section 121 requirements are not applicable. This action is protective of human health and the environment and is meant to be a permanent solution, final action, for the Grace Road Site. No five-year remedy review is needed or will be performed.

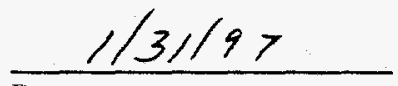

Date

\section{$3 \backslash 27197$}

Date

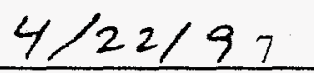

Date

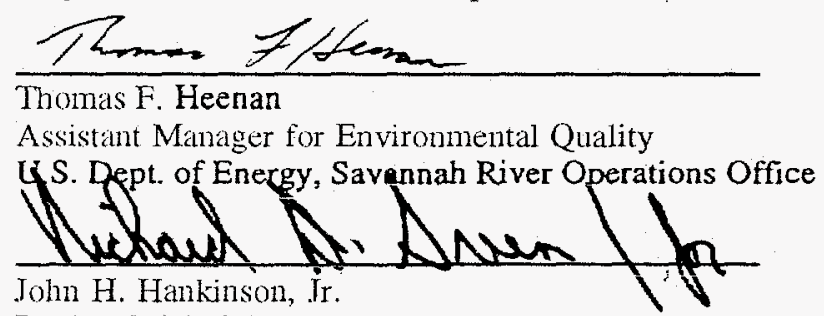

Regional Administrator

U.S. Environmental Protection Agency, Region IV

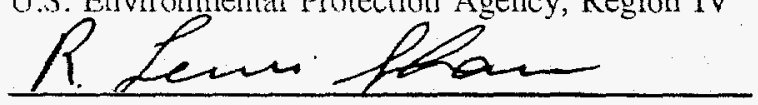

R. Lewis Shaw

Deputy Commissioner

Environmental Quality Control

South Carolina Deparment of Health and Environmental Control 
This page left intentionally blank 


\title{
Decision Summary Remedial Alternative Selection (U) for the Grace Road Site (631 -22G) Operable Unit: Final Action
}

\author{
WSRC-RP-96-O0160 \\ Revisional \\ January 1997
}

Prepared by:

Westinghouse Savannah River Company

Aiken, South Carolina

Prepared for the U.S. Department of Energy Savannah River Operations Office Under Contract DE-AC09-96SR1 8500 
This page left intentionally blank 


\section{DECISION SUMMARY}

TABLE OF CONTENTS

$\underline{\text { Section }}$

Page

I.

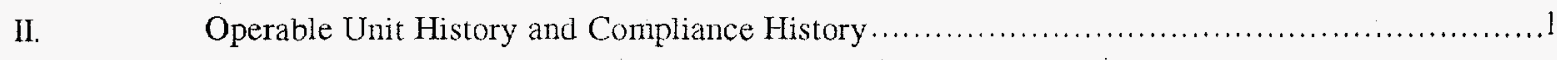

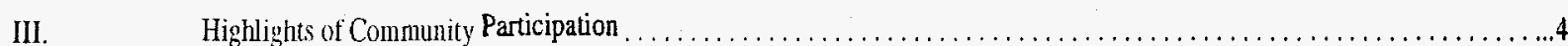

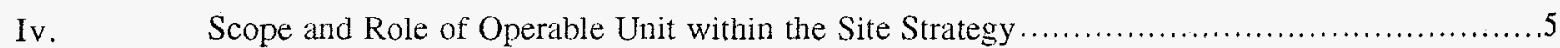

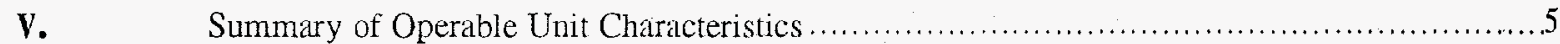

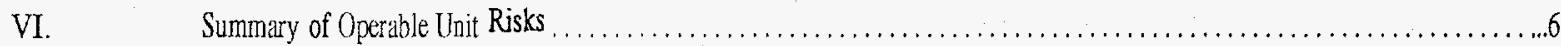

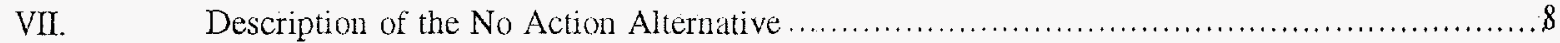

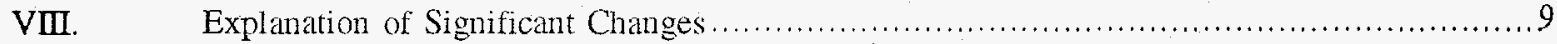

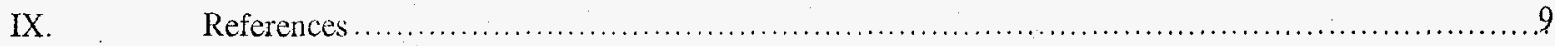

\section{List of Figures}

Figure 1. Location of Grace Road Site in Relation to Major SRS Facilities

Figure 2. General Configuration of the Grace Road Site

List of Tables

Table 1. Comparison of unit specific soil concentrations to two times background concentrations and risk-based concentrations (RBC).

Table 2 Carcinogenic/Non-carcinogenic results for Arsenic

Appendix

A. Responsiveness Summary 
This page left intentionally blank 


\section{Site and Operable Unit Name,} Location, and Description

The Savamah River Site (SRS) occupies approximately 803 square kilometers (310 square miles) of land adjacent to the Savannah River, principally in Aiken and Barnwell Counties of South Carolina (Figure 1). SRS is a secured U.S. government facility with no permanent residents. SRS is located approximately 40 kilometers (25 miles) southeast of Augusta, Georgia, and 32 kilometers $(20$ miles) south of Aiken, South Carolina.

SRS is owned by the Department of Energy (DOE). Management and operating services are provided by Westinghouse Savannah River Company (WSRC). SRS has historically produced tritium, plutonium, and other special nuclear materials for national defense. SRS has also provided nuclear materials for the space program and for medical, industrial, and research efforts. Chemical and radionctive wastes are by-products of nuclear material production processes.

The Federal Facility Agreement (FFA, 1993) for SRS lists the Grace Road Site $(631-22 G)$ as a RCRA/CERCLA unit that required further evaluation.

The Grace Road Site is located approximately 1.3 kilometers $(0.8 \mathrm{mi})$ south of B-Area and about 244 meters ( 800 yards) east of the intersection of Grace Road and SRS Road 2. The unit is roughly rectangular in shape and has a northwest-southeast orientation running parallel to Grace Road (Figure 2). The unit is approximately 396.3 meters (1300 ft) by 97.6 meters $(320 \mathrm{ft})$. It covers an area of about 3.8 hectares $(9.6$ acres).

The Grace Road Site consisted of numerous drums and cans, concrete slabs, brick foundations (pre-SRS) and miscellaneous debris. Small mounds of concrete, bricks, shingles, car and truck parts and large concrete blocks that appeared to be pieces of a bridge were also found at the unit. The unit also contained numerous drums and cans varying in size from $1 / 2$ gallon cans to 55 gallon drums and various car parts. Most of the debris was on the surface or partially buried in scattered locations across the unit. Markings on a few of the smaller drums and cans indicated that they once contained oil and grease. There is no evidence that any recent disposal activity has occurred or that the disposal activity was more widespread. Also, there is no evidence of any burning or excavation at this waste unit.

\section{Operable Unit History and Compliance History}

\section{Operable Unit History}

Prior to the establishment of SRS, Grace Road Site was part of a tenant-operated farm owned by Mrs. Elise Grace. The farm consisted of about 217.6 hectares (544 acres) of which 92 hectares (230 acres) were under cultivation, and the remaining 125.6 hectares (314 acres) were in woodlands and swamp lands. Transfer records of this land to the U. S. Government in January 1951 indicate that this land had been a farm (part of the Red Hill Plantation) since the late 1890s.

Buildings on the farm consisted of a main house, dog kennel, machine shed, oil house, two cottages, two turkey houses, two barns, garage, cook house, twostory barn, water tower with meat house, storage shed, grain storehouse, hay storage barn and an outhouse (privy). The majority of the buildings had a foundation of bricks, concrete or tile blocks. Several buildings, including the dog kennels and turkey houses, had concrete slab floors. The water tower also had massive concrete blocks that were used to hold treated timber stanchions that supported the water tank. Photographs of the farm show at least two gasoline powered tractors in the machine shed, a truck and other assorted farm machinery.

After purchase by the Government, the area in and around the farm was utilized as a laydown yard for materials used in the construction of the B Area. The length of time that it was utilized for this purpose is unknown, but is estimated to be two to three years. There are no records to indicate that this unit has been used for any other purpose since it was closed as a laydown yard in the mid-1950s.

Between February and May 1992, all the debris, drums and concrete slabs were removed from the Grace Road Site. The items removed were either used at soil erosion control areas or were disposed of in the sanitary landfill. The EPA and SCDHEC granted approval prior to SRS removing the materials from the waste unit.

No records of any type of waste management activity have been found for the Grace Road Site. Based upon available information, i.e., literature search and records search, no hazardous materials have been managed or disposed of at Grace Road.

\section{Compliance History}

At SRS, waste materials regulated under the Resource Conservation and Recovery Act (RCRA) are managed in accordance with the requirements of RCRA. Certain SRS activities have required treatment, storage, disposal 


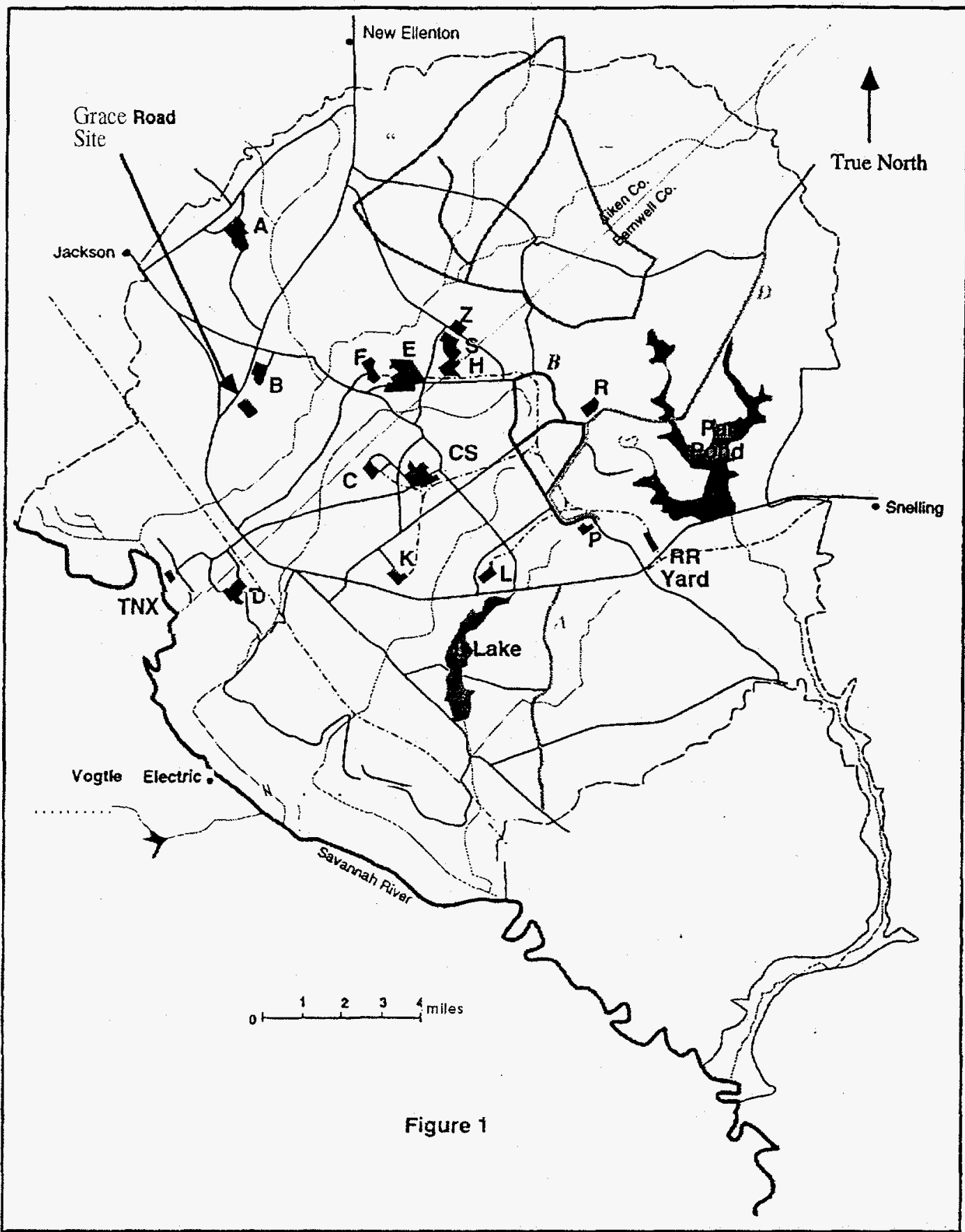

Figure 1. Location of the Grace Road Site at the Savannah River Site. 


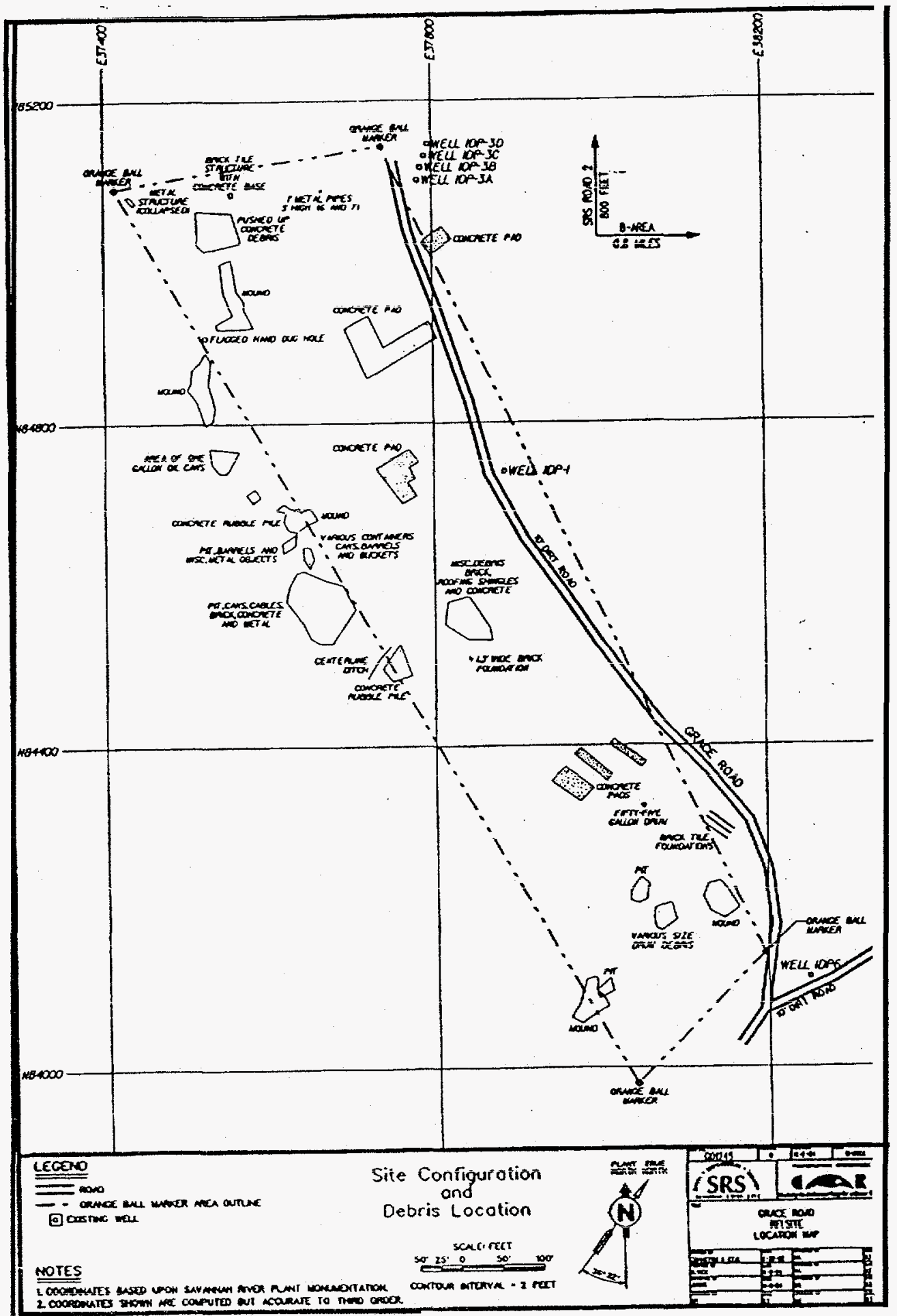

Figure 2. General configuration of the Grace Roadside. 
or post-closure permits under RCRA. Non-regulated units, called solid waste management units (SWMU), include any activity where hazardous constituents may remain uncontrolled and may potentially release to the environment. Investigation and potential corrective action for these SWMU(s) are mandated under RCRA 3004(U). In 1995, SRS received a hazardous waste permit from the South Carolina Deparment of Health and Environmental Control (SCDHEC) which includes corrective action requirements. Specifically, part V of the permit mandates that SRS establish and implement a RCRA Facility Investigation (RFI) Program to fulfill the requirements specified in Section 3004(u) of RCRA.

Hazardous substances, as defined by CERCLA, are also present in the environment at SRS. On December 21, 1989, SRS was placed on the National Priorities List (NPL). A site placed on the NPL comes under the requirements of CERCLA. In accordance with Section 120 of CERCLA, DOE has entered into an FFA with the EPA and SCDHEC to coordinate cleanup activities at SRS into one comprehensive strategy that fulfills RCRA Section 3004(u) and CERCLA assessment, investigation, and response action requirements.

The remedial investigation for Grace Road Site was completed in 1994. The results of the investigation indicate that there is no impact (or potential impact) to human health or the environment from the Grace Road Site. Therefore, no action is warranted. No other alternatives were considered.

According to EPA guidance, if there is no current or potential threat to human health and the enviromment and no action is warranted, the CERCLA 121 reguirements are not triggered. This means that there is no need to evaluate other alternatives or the no action alternative against the nine criteria specified under CERCLA.

The remedy selected satisfies both the CERCLA and RCRA 3004(u) requirements. The SCDHEC has modified the SRS RCRA permit to incorporate the selected remedy.

Public participation requirements are listed in Sections 113 and 117 of CERCLA. These requirements include the establishment of an Administrative Record File that documents the selection of remedial alternatives and allows for review and comment by the public regarding those alternatives. The Administrative Record File must be established "at or near the facility at issue." The SRS Public Involvement Plan (DOE, 1994) is designed to facilitate public involvement in the decision-making process for permitting, closure, and the selection of remedial alternatives. Section $117(\mathrm{~A})$ of CERCLA, as amended, requires the preparation of a proposed plan as part of the site remedial process. The
Statement of Basis/Proposed Plan for the Grace Road Site (WSRC, 1996a), which is part of the Administrative Record File, highlights key aspects of the investigation and identifies the preferred action for addressing of the Grace Road Site.

The statement of basis/proposed plan (SB/PP) submitted fulfills the requirements of CERCLA Section 117 (a) by providing the public an opportunity to participate in the remedy selection process. The SB/PP presented the preferred alternative and the rationale for selecting the alternative. DOE, in consultation with EPA - Region IV and SCDHEC, selected the final action for the Grace Road Site following the public comment period.

\section{Highlights of Community Participation}

The Administrative Record File, which contains information pertaining to the selection of the response action, is and has been available at the following locations:
U.S. Department of Energy
Public Reading Room
Gregg-Graniteville Library
University of South Carolina-Aiken
171 University Parkway
Aiken, South Carolina 29801
(803) 641-3465
Thomas Cooper Library
Government Documents Department
University of South Carolina
Columbia, South Carolina 29208
(803) $777-4866$

Similar information was also made available through the following repositories:
Reese Library
Augusta State University
2500 Walton Way
Augusta, Georgia 30910
(706) $737-1744$
Asa H. Gordon Library
Savannah State University
Tompkins Road
Savannah, Georgia 31404
(912)356-2183

The public was notified of the comment period for the SB/PP through mailings of the SRS Environmental Bulletin, a newsletter sent to more than 3400 citizens in South Carolina and Georgia, and through notices in many local newspapers. 
The 45-day public comment period began on September 17, 1996, and ended on October31, 1996. No comments were received.

\section{I.v. Scope and Role of Operable Unit within the Site Strategy}

The overall strategy for addressing the Grace Road Site was to: 1) determine if there had been a release of hazardous substances; 2) determine the nature and extent of any contamination; 3) perform a baseline risk assessment; and 4) evaluate the need for remedial action to address any potential risk to human health and the environment.

The investigation and risk assessment have been completed for the Grace Road Site. Since the results of the investigation indicate that there is no impact to human health or the environment, no action was recommended.

The Grace Road Site is part of the larger Upper Three Runs watershed consisting of several surface and groundwater units. The Grace Road Site does not contribute contamination to groundwater within the watershed. Although the risk assessment indicated that the Grace Road Site does not impact human health or the environment, arsenic was detected above unit specific background. The arsenic does not appear to be from the waste unit. It is possible it is from farming activities prior to SRS being built. Arsenic has also been detected at several other waste units and other Site areas. Arsenic will be evaluated on a Site-wide basis as part of the Soil Background Study.

\section{v. Summary of Operable Unit Characteristics}

There is no documented information available regarding pasi hazardous or non-hazardous waste disposal activities at the Grace Road Site. Markings on the drums found at the unit suggest that they once contained oil and grease. There is no evidence that any recent disposal activity has occurred or that the disposal activity was more widespread. Also, there is no evidence of any burning or excavation at this waste unit.

\section{Media Assessment.}

Only surface disposal activities appear to have occurred at the Grace Road Site. Based on this, the conceptual release model consisted of a release to surface soils with a potential for leaching to subsurface soils. Therefore, only surface and subsurface soils were investigated. For a detailed explanation of the release model, potential receptors and the fate and transport of contamination, see the RFI/RI report for the Grace Road Site 631 .
22G), WSRC-RP-95-93 (WSRC, 1996b).

Soil/vadose zone and groundwater investigations were conducted between 1990 and 1994. The initial investigation was based on a 1988 soil gas survey which detected low levels of hydrocarbons and chlorinated hydrocarbons. Detailed descriptions of the investigation and characterization conducted at the Grace Road Site. may be found in the RCRA Facility Investigation/Remedial Investigation Report for the Grace Road Site (631-22G), WSRC-RP-95-93 (WSRC, 1996b) and the RCRA Facility Investigation Remedial Investigation Plan for the Grace Road Site WSRC-RP90-1250 (WSRC, 1990).

\section{Groundwater}

Groundwater data from wells near the Grace Road Site indicate that there is no groundwater contamination.

\section{Surface Water/Sediment}

No surface water or sediment sampling was conducted because the nearest surface water feature is located over 1 mile from the Grace Road Site.

soils

The soils investigation was designed to assess the horizontal extent and vertical migration of any hazardous constituents at the unit and to evaluate (prove/disprove) the release model.

The soils investigation included taking soil samples (1990 and 1994), an electromagnetic survey (1990), a ground penetrating radar (GPR) survey (1994) and a soil gas survey (1994).

The magnetometer survey and the GPR survey indicate that there are no buried materials at the unit.

An extensive soil gas survey was performed in 1994. A total of 85 sample locations were established and samples collected at each location. Species monitored for this survey were: light hydrocarbons; gasoline range normal paraffins; gasoline range aromatic hydrocarbons; diesel range hydrocarbons; selected organics; and mercury.

The level of volatiles and diesel range organics observed in the survey were very low with most below minimum detection levels. Levels of light hydrocarbons and mercury were indicative of background concentrations in the SRS area. No evidence of contamination was detected at this unit by the soil gas survey.

Confirmation soil sampling served as a screening for semi-volatile and volatile organic compounds, metals, 
and radionuclides. In addition, Appendix IX parameters were also analyzed. Results from the soil gas survey conducted in 1988 and the location of the debris/rubble were used to select soil sample locations. Background samples were also obtained for comparison purposes.

Metals found in concentrations greater than analytical method detection limits were arsenic, barium, cadmium, chromium, mercury, lead, selenium, tin, vanadium and zinc. Acetone, methylene chloride and bis(2. ethylhexyl)phthalate were also detected. Phthalate species are used as plasticizers for cellulose, glass, plastic, and rubber products. Other substances detected, such as acetone, xylene, and methylene chloride are commonly used as laboratory solvents. Radionuclide indicator parameters (gross alpha, non-volatile beta) were within background. See Table 1 for constituent concentrations and background levels.

The concentration levels of the analytes, with the exception of arsenic and lead, were within background levels. The concentration level of arsenic detected at the unit, ranged from 2.6 to $3.2 \mathrm{mg} / \mathrm{kg}$ and for lead, the range is 0.9 to $48.1 \mathrm{mg} / \mathrm{kg}$.

The level of arsenic detected is consistent with the levels found throughout SRS. The arsenic may be naturally occurring or added to the soils as a pesticicle prior to SRS operations. Arsenic will be evaluated on a Site-wide basis during the implementation of the Sitewide Soils Background Study.

\section{Summary of Operable Unit Risks}

\section{Human Health Risks}

As part of the RCRA/CERCLA process for the Grace Road Site, a risk assessment was performed using data generated during the assessment phase. Detailed information regarding the development of chemicals of potential concern, fate and transport of contaminants and risk assessment can be found in the RFLRI Report for Grace Road Site (631-22G), WSRC-RP-95-93 (WSRC, 1996b).

After combining analytical data and eliminating those analytes not detected in any samples, the data were evaluated on the basis of quality with respect to sample quantitation limits, frequency of detection, relative toxic polential of the constituent, laboratory qualifiers and codes, and blanks. The remaining data (constituents detected) were compared to two times the unit-specific background and EPA developed Risk-Based Concentrations (RBCs).

RBCS developed by EPA Region III (EPA, 1995) were used to screen the chemicals of potential concern for the Grace Road Site. This guidance provides reference doses and carcinogenic potency data for nearly 600 chemicals. These toxicity constants have been combined with "standard" exposure scenarios to calculate RBCS chemical concentrations corresponding to fixed levels of risk (i.e., a hazard quotient of 1 , or a lifetime cancer risk of one in one million). The RBCS are very similar to preliminary remediation goals which are concentration goals for individual chemicals for a specific medium and land use combinations at CERCLA units.

Following the comparison to background and RBCS (Table 1), only two chemicals remained to be studied further, arsenic and lead.

The screening level for lead in soil is $400 \mathrm{mg} / \mathrm{kg}$ for residential land use. This value is described in OSWER Directive \# 9355.4-12, Revised Internal Soil Lead Guidance for CERCLA Sites and RCRA Corrective Action Facilities, dated July 14, 1994 and issued by the USEPA (EPA, 1994). Because lead concentrations range from 0.9 to $48.1 \mathrm{mg} / \mathrm{kg}$, which are far below the EPA guidance level, lead was eliminated as a COPC.

Since arsenic was not eliminated from the screening process, calculations were performed to determine the risk for the on-unit resident scenario. Note, however, that arsenic was used as a component of agricultural chemicals in the period before SRS existed and that Grace Road was a farm. Thus, a few of the detected values may be a result of farming activities prior to 1950. SRS wide values for arsenic range from less than $0.5 \mathrm{mg} / \mathrm{kg}$ to $15.2 \mathrm{mg} / \mathrm{kg}$. The SRS maximum concentration level for arsenic in Blanton (the soils type found at (Grace Road) soils is $7.05 \mathrm{mg} / \mathrm{kg}$.

Only one land use scenario was considered: future land use (residential). The potential human receptor addressed was a hypothetical future on-unit resident. A current on-unit worker scenario was not performed because no worker activity is conducted in the area.

Cancer risks are estimated as the incremental probability of an individual developing cancer over a lifetime as a result of pathway-specific exposure to carcinogenic contaminants. The risk to an individual resulting from exposure to non-radioactive chemical carcinogens is expressed as the increased probability of a cancer occurring over the course of a 70 year lifetime. Cancer risks are related to the EPA target range of one in ten thousand $\left(1 \times 10^{-14}\right)$ to one in one million $\left(1 \times 10^{-06}\right)$ for incremental cancer risk at NPL sites. In order to account for simultaneous exposure to multiple carcinogens through a given pathway, the risks calculated for each individual carcinogen in that medium were summed to obtain an estimate of the total cancer risk for the pathway. 
Table 1. COMPARISON OF UNIT SPECIFIC SOIL CONCENTRATION TO TWO TIMES BACKGROUND CONCENTRATIONS AND RISK - BASED CONCENTRATIONS (RBC)

\begin{tabular}{|c|c|c|c|c|}
\hline Contaminant (units) & \begin{tabular}{|l|} 
Maximum \\
Concentration \\
\end{tabular} & $\begin{array}{l}\text { Average Background Soil } \\
\text { Concentration (GRS-10) }\end{array}$ & $\begin{array}{l}\text { Two Times } \\
\text { Background }\end{array}$ & $\begin{array}{l}\text { RBC Value* } \\
\text { (mg/kg) }\end{array}$ \\
\hline $\begin{array}{l}\text { Bis(2-ethylhexyl) } \\
\text { Phthalate (mg/kg) }\end{array}$ & 6.8 & 4.7 & 9.4 & 46 \\
\hline Carbon Disulfide (mg/kg) & $0.002 \mathrm{~J}$ & Not Detected & Not Detected & 7800 \\
\hline$\overline{\mathrm{DDT}(\mathrm{mg} / \mathrm{kg})}$ & $0.0063 \mathrm{~J}$ & Not Detected & Not Detected & 1.9 \\
\hline Styrene (mg/kg) & $0.004 \mathrm{~J}$ & Not Detected & Not Detected & 16000 \\
\hline Acetone (mg/kg) & $0.002 \mathrm{~J}$ & Not Detected & Not Detected & 7800 \\
\hline Toluene $(\mathrm{mg} / \mathrm{kg})$ & $0.003 \mathrm{~J}$ & Not Detected & Not Detected & 16000 \\
\hline Di-n-Butyl Phthalate (mg/kg) & $53 \mathrm{~J}$ & Not Detected & Not Detected & 7800 \\
\hline Trichloroethylene (mg/kg) & 0.004 & Not Detected & Not Detected & 58 \\
\hline Xylene $(\mathrm{mg} / \mathrm{kg})$ & 0.007 & Not Detected & Not Detected & 160,000 \\
\hline Arsenic (mg/kg) & 3.2 & Nol Detected & Not Detected & 0.37 \\
\hline Barium (mg/kg) & 48.4 & Not Detected & Not Detected & 5500 \\
\hline Cadmium (mg/kg) & 1.8 & Not Detected & Not Detected & 39 \\
\hline Chromium (VI) (mg/kg) & 29.6 & 4.2 & 8.4 & 390 \\
\hline Mercury (mg/kg) & 0.15 & Not Detected & Not Detected & 23 \\
\hline Lead (mg/kg) & 48.1 & 1.4 & 2.8 & $400 * *$ \\
\hline Selenium (mg/kg) & 1.3 & Not Detected & Not Detected & 390 \\
\hline Tin $(\mathrm{mg} / \mathrm{kg})$ & 32.5 & Not Detected & Not Detected & 47000 \\
\hline Vanadium (mg/kg) & 61.8 & Not Detected & Not Detected & 550 \\
\hline Zinc (mg/kg) & 7.0 & Not Detected & Not Detected & 23000 \\
\hline
\end{tabular}

* EPA Region III, Risk-Based Concentration Table, January-June 1995, dated March 7, 1995

$\mathrm{I}=$ estimated value

** The screening level for lead in soil is $400 \mathrm{mg} / \mathrm{kg}$ for residential land use. This value is described in OSWER Directive \# 9355.4-12, Revised Internal Soil Lead Guidance for CERCLA Sites and RCRA Corrective Action Facilities, dated July 14, 1994 and issued by Elliot P. Lewis of the USEPA. The screening level for lead was calculated using the USEPA new integrated exposure uptake biokinetic model with default parameters.

Table 2. Carcinogenic/Non-Carcinogenic Results for $3.2 \mathrm{mg} / \mathrm{kg}$ Arsenic.

\begin{tabular}{|l|l|l|l|}
\hline \multirow{3}{*}{ Pathway } & Carcinogenic Risk & Non-Carcinogenic Risk & \\
\cline { 3 - 4 } & Adult and Child (Unitless) & Adult and Child (Unitless) & $\begin{array}{l}\text { Child only } \\
\text { (Unitless) }\end{array}$ \\
\hline Dermal Contact & $4.7 \times 10-08$ & 0.00039 & 0.00026 \\
Ingestion & $8.8 \times 10-06$ & 0.15 & 0.14 \\
Inhatation & $2.9 \times 10^{-15}$ & 0.055 & 0.047 \\
\hline Total Risk & $3.8 \times 10^{-45}$ & 0.2 & 0.19 \\
\hline
\end{tabular}


Non-carcinogenic effects are evaluated by comparing an exposure level over a specified time period (e.g., lifetime) with a reference dose (RfD) derived for a similar exposure period. To evaluate the noncarcinogenic effects of exposure to soil contaminants, the hazard quotient (HQ), (the ratio of the exposure dose to the RfD) is calculated for each contaminant. The non-carcinogenic HQ assumes that below a given level of exposure (i.e., the RfD), even sensitive populations are unlikely to experience adverse health effects. HQs are summed for each exposure pathway to create a pathway specific hazard index $(\mathrm{HI})$ for each exposure scenario. The more the HI exceeds one (1), the greater the concern that adverse health effects will occur. The hazard quotient is not a percentage or probability.

The maximum concentration value was used as the exposure point concentration.

\section{Current Land Use}

Since there is no current activity at the Grace Road Site, the current land use scenario is not applicable.

\section{Future Land Use}

Under the future land use scenario, carcinogenic risks and non-carcinogenic hazards were calculated for exposure of the future on-unit resident (adult and child) to surface soils and air. The on-site resident scenario was used because it is more conservative than the industrial scenario.

The estimate of the total risk for carcinogens, for the future residential scenario, is $3.8 \times 10-05$. All estimated carcinogenic risk is due to arsenic.

The cancer risk from the ingestion of soil at the Grace Road Site was $8.8 \times 10-6$. Estimated risk was $4.7 \times 10-8$, below the EPA point of departure of $1 \times 10-6$, for dermal contact with soils at the unit. Total cancer risk for inhalation of particulate from soils at Grace Road is $2.9 \times 10^{-5}$ which is above the EPA point of departure of $1 \times 10^{-6}$, but within the $1 \times 10^{-4}$ to $1 \times 10^{-6}$ range of concern. Arsenic is the responsible contaminant for the above risk estimates. The levels of arsenic detected are consistent with the levels found throughout SRS.

The non-carcinogenic HI for the soil pathways were calculated for adulthood and childhood exposures combined and for childhood exposure only. All of the exposure pathways for the on-unit resident have a noncarcinogenic hazard/risk of less than one.

\section{Ecological Risks}

The ecological information base for Grace Road Site consists of a unit-specific threatened, endangered and sensitive species survey and a unit-specific ecological reconnaissance. Additional information is contained in the existing unit history, preliminary unit evaluation, and unit characterization data. This information can be summarized as follows:

- There is no evidence of vegetation stress or ecological impact related to the unit;

- There are no threatened or endangered species known to exist at or in the vicinity of the unit;

- Review of the unit characterization data indicates that there are no constituents in the physical media at Grace Road which are significantly different from the unit specific background condition.

Based on the physical and analytical data obtained for this unit, there is no compelling evidence that waste materials were managed or disposed at Grace Road. Therefore, it is reasonable to conclude that the unit presents no significant ecological risk.

\section{Description of the No Action Alternative}

Based on the risk assessment, the only contaminant contributing to a risk above $\mathrm{lx} 10^{-6}$ is arsenic. The levels of arsenic present, which pose no unacceptable risk to human health or the environment, do not appear to be associated with the disposal actvities at the Grace Road Site. Therefore, no action is needed at Grace Road Site and no other alternatives were considered. However, arsenic will be evaluated on a Site-Wide basis during the Site-wide Soils Background Study.

Under the No Action alternative, no treatment will be performed because there is no waste to treat. No new institutional controls or engineering controls will be implemented and there is no cost associated with implementing the alternative. According to CERCLA regulations, Section 121, if no action is the preferred action, then no Applicable, Relevant and Appropriate Requirements (ARARs) apply to the waste unit.

Since Grace Road Site poses no risk and the no action alternative is warranted, it does satisfy the CERCLA criteria. The no action alternative is intended to be the final action for Grace Road Site. This solution is meant to be permanent and effective in both the long and short term. The no further action decision is the least cost option with no capital, operating, or monitoring cost and is protective of human health and the environment. SCDHEC has modified the SRS RCRA permit to reflect this ROD. 


\section{Explanation of Significant Changes}

No significant changes were made to the Record of Decision based on the public comment period for the proposed plan.

\section{References}

DOE (U.S. Department of Energy), 1994. Public Involvement, A Plan for the Savannah Riverside. Savannah River Operations Office, Aiken, South Carolina.

EPA (U.S. Environmental Protection Agency), 1989 Guidance on Preparing Superfund Decision Documents Office of Solid Waste and Emergency Response - OSWER Directive 9355.3-02.

EPA (U.S. Environmental Protection Agency), 1991a. Role of Baseline Risk Assessment in Superfund Remedy Selection Decisions. Office of Solid Waste and Emergency Response - OSWER Directive 9355.0-30.

EPA (U.S. Environmental Protection Agency), 1994 Revised Internal Soil Lead Guidance for CERCLA Sites and RCRA Corrective Actions Office of Solid Waste and Emergency Response - OSWER Directive 9355.4-12.

EPA (U.S. Environmental Protection Agency), RiskBased Concentration Table, EPA-III, January-June 1995, dated March 7, 1995

FFA, 1993. Federal Facility Agreement for the Savannah River Site, Administrative Docket Number 89-05-FF (effective date: August 16, 1993).

WSRC (Westinghouse Savannah River Company), RCRA Facility Investigation Remedial Investigation Plan for the Grace Road Unit (U), WSRC-RP-90- 1250, Rev.0, Westinghouse Silvannah River Company, Aiken, SC, (1990).

WSRC (Westinghouse Savannah River Company), Statement of Basis/Proposed Plan for the Grace Road Site: Final Action (U) WSRC-RP-96-105 (1996a)

WSRC (Westinghouse Savannah River Company), RFI/RI Report for Grace Road Site $(631-22 G)(U)$, WSRC-RP-95-93, Rev. 1, Westinghouse Savannah River Company, Aiken, SC. (includes baseline risk assessment) (1996b) 
APPENDIX A

RESPONSIVENESS SUMMARY

No conments received 